\title{
Apercepcja i sąd. Rozważania wokół transcendentalnej dedukcji kategorii
}

\section{Wstęp}

Termin „apercepcja” pojawia się pierwotnie u Leibniza w Nowych rozważaniach, Rozprawie metafizycznej, Zasadach natury i łaski oraz Monadologii. $\mathrm{W}$ dziełach tych można zauważyć dwa sposoby rozumienia/dwa poziomy apercepcji: niższy, polegający na ujmowaniu, uświadamianiu sobie (treści) percepcji, tj. sprowadzanie treści percepcji do syntetycznej jedności, oraz wyższy, w którym uchwytuje się (uświadamia się) istnienie Boga, prawd wiecznych i własnego Ja.

Kant - podobnie jak Leibniz - także odróżnia dwa poziomy apercepcji: apercepcję empiryczną oraz apercepcję transcendentalną. Apercepcja empiryczna to zwykła świadomość swego stanu wewnętrznego, tzn. polega ona na tym, że uświadamiam sobie ten stan, tj. to, że się w nim znajduję. W apercepcji empirycznej, którą Kant utożsamia ze zmysłem wewnętrznym, jestem świadomy jedynie własnych stanów mentalnych. Natomiast w a p e r c e p cj i transcendentalnej jestem świadomy czegoś więcej. Co stanowi owo 
coś więcej? Otóż dzięki transcendentalnej apercepcji traktujemy wewnętrzne stany mentalne jako reprezentacje, tj. - mówiąc językiem Kanta - pr ze dstawienia (Vorstellungen). Przedstawienia są przedstawieniami czegoś, a nie po prostu wewnętrznymi stanami mentalnymi w sobie, czyli „subiektywnymi modyfikacjami naszej zmysłowości”, transcendentalna apercepcja ma wobec tego istotny związek z in t e n c j o n a ln o ści ą. Wstępnie naszkicowana powyżej różnica pomiędzy oboma typami apercepcji jest ukazana dalece niewystarczająco, a nawet może nasuwać błędne interpretacje. W prezentowanym artykule staram się tę różnicę rozjaśnić.

Zasadnicze rozważania dotyczące transcendentalnej apercepcji przeprowadza Kant w rozdziałach poświęconych transcendentalnej dedukcji kategorii Krytyki czystego rozumu, a jej rola uwidacznia się szczególnie w rozwijanej tam koncepcji sądu. Jest to perspektywa epistemologiczna. Natomiast w rozdziale o paralogizmach ujęcie apercepcji występuje w kontekście przede wszystkim polemicznym, ma charakter uzupełniający, a celem jest krytyka psychologii racjonalnej, która w centrum stawia problem duszy jako podmiotu apercepcji. Tym razem rozważania prowadzone są przede wszystkim w perspektywie ontologicznej.

Rezultaty tych dwóch ujęć apercepcji wydają się pozostawać w konflikcie. Twierdzi się, jak na przykład czynią to H. Allison ${ }^{1}$ i S. Judycki ${ }^{2}$, ze Kant zajmował dwa niezgodne wzajemnie ze sobą stanowiska w kwestii natury apercepcji, a w konsekwencji także podmiotu apercepcji. W transcendentalnej dedukcji kategorii miał on uznać, że podmiot transcendentalnej apercepcji jest tożsamy z podmiotem noumenalnym (noumenalnym Ja), a w paralogizmach, że te dwa podmioty są różne. Twierdzi się ponadto, że to drugie, tzw. alternatywne stanowisko Kanta jest tym właściwym. Można mieć jednak wątpliwości, czy tak jest w istocie: czy Kant faktycznie przyjmował dwie różne koncepcje podmiotu apercepcji? Tak czy inaczej, istotniejsza wydaje się jednak natura i funkcja samej apercepcji niż kwestia tego, co jest jej podmiotem.

Celem artykułu jest rekonstrukcja poglądów Kanta na transcendentalną apercepcję, przede wszystkim jej roli w akcie sądzenia. Rekonstrukcja ta zawiera pewną propozycję interpretacyjną, polegającą na tym, że przyjmuję, iż podstawowym sensem transcendentalnej apercepcji jest forma aktu sądzenia. Innymi słowy, zamierzam pokazać, że stwierdzenie, iż transcendentalna

${ }^{1}$ H. Allison, Kant's Transcendental Idealism. An Interpretation and Defense, New Haven-London 1983.

${ }^{2}$ S. Judycki, Kantowska teoria umystu, „Roczniki Filozoficzne”, t. XLV, 1997, z. 1, s. 35-60. 
apercepcja jest świadomością siebie, tj. samoświadomością, nie jest wystarczające - jest to co najwyżej jeden z jej aspektów ${ }^{3}$.

\section{Transcendentalna apercepcja $\mathrm{w}$ świetle dedukcji kategorii}

W różnych miejscach Krytyki czystego rozumu można znaleźć rozmaite sformułowania zawierające charakterystyki transcendentalnej apercepcji, które na pierwszy rzut oka mogą się wydawać rozbieżne i trudne do pogodzenia. Rozpocznijmy od przypomnienia określenia znajdującego się na początku paragrafu 16 tego dzieła:

Przedstawienie [Ja] „Myślę” musi móc towarzyszyć wszystkim mym przedstawieniom, inaczej bowiem byłoby coś we mnie przedstawione, co wcale nie mogło być pomyślane. Znaczy to akurat tyle, co to, że przedstawienie byłoby albo niemożliwe, albo że przynajmniej dla mnie byłoby niczym. Przedstawienie, które może być dane przed wszelkim myśleniem, nazywa się daną naoczną. Wszelka różnorodność danych naocznych zawiera więc w sobie konieczne odniesienie do owego „Myślę" występujące w tym samym podmiocie, w którym znajduje się ta różnorodność.

Przedstawienie to jest jednak aktem samorzutności, tzn. nie można go uważać za należące do zmysłowości. Nazywam je dla odróżnienia od empirycznej apercepcji apercepcją czystą lub też apercepcją pierwotną, ponieważ jest ono tą samowiedzą (Selbstbewusstsein), która wytwarzając przedstawienie [Ja] „Myślę" - które musi móc towarzyszyć wszelkim innym przedstawieniom i we wszelkiej świadomości jest jedno i to samo - nie może już sama być wyprowadzona z żadnego innego przedstawienia. Jedność tej apercepcji nazywam też transcendentalną jednością samowiedzy, ażeby zaznaczyć możliwość pochodzenia z niej poznania a priori $(K r V$ B 132) .

\footnotetext{
${ }^{3}$ Pragnę wyrazić podziękowania dla Marka Pyki i Jana Wawrzyniaka za przeczytanie pierwszej wersji tekstu i uwagi.

${ }^{4}$ Wszystkie cytaty z Kanta podaję za wydaniem: Krytyka czystego rozumu, t. I i II, przeł. R. Ingarden, PWN, Warszawa 1957; aby nie obciążać tekstu nadmierną ilością przypisów, podaję jedynie skrótowe oznaczenie dzieła: $\mathrm{KrV}$ oraz numer strony według wydań niemieckich $(\mathrm{A} / \mathrm{B})$.
} 
Transcendentalna apercepcja „Ja myślę” występuje tu w roli najwyższej zasady: „Zasada syntetycznej jedności apercepcji jest najwyższą zasadą wszelkiego posługiwania się intelektem" ( $K r V \mathrm{~B} 136$ ), która głosi:

Najwyższą zasadą tejże właśnie możliwości odniesienia do intelektu jest to, że wszystko, co różnorodne w naoczności, podlega warunkom pierwotnej syntetycznej jedności apercepcji... [...] (KrV B 136-137).

[....] syntetyczna jedność apercepcji jest najwyższym punktem, w którym trzeba utwierdzić wszelki użytek intelektu, nawet całą logikę, a po niej i filozofię transcendentalną. Co więcej, ta zdolność jest samym intelektem ( $K r V$ B 134).

Przytoczone fragmenty skłaniają do zastanowienia się nad tym, jaki jest podstawowy sens owej transcendentalnej jedności apercepcji. Czy chodzi tu o uchwycenie samego owego Ja?, to znaczy: czy akt uchwycenia samego owego Ja jest właśnie ową poszukiwaną apercepcją; czy raczej (jak sądzi A. Brook ${ }^{5}$ i A. Dickerson ${ }^{6}$ ), że podstawowa jest tu rola transcendentalnej apercepcji w nadawaniu jedności pewnej wielości, tzn. chodziłoby o funkcję związaną z wytwarzaniem złożonych przedstawień? W tym drugim przypadku idzie raczej o ujęcie rozmaitych wytworzonych przedstawień jako jedno przez pierwotną jedność, jaką ma wykazywać sam podmiot apercepcji. Wydaje się, że roli transcendentalnej apercepcji nie można redukować, to jest sprowadzać do jednego tylko zasadniczego rysu bądź funkcji. Aby dostrzec niewystarczalność takiego jednostronnego podejścia, wystarczy rozważyć drugi istotny aspekt transcendentalnej apercepcji, a mianowicie fakt, że występuje ona jako for m a źród ło wa wszelkiego przedstawienia.

Przez owo Ja, [...] które myśli, nie przedstawiamy sobie nic więcej jak tylko transcendentalny podmiot myśli $=\mathrm{x}$, który poznajemy jedynie poprzez myśli stanowiące jego określenia; o nim samym w odosobnieniu nie możemy mieć nawet najmniejszego pojęcia. Krążymy więc stale dookoła niego, albowiem, by cokolwiek o nim sądzić, musimy już zawsze rozporządzać jego przedstawieniem; niedogodność, której niepodobna uniknąć, ponieważ świadomość sama $\mathrm{w}$ sobie jest nie tyle przedstawieniem, które wyróżnia pewien specjalny przedmiot, ile formą przedstawienia wogóle, o ile ono ma nazywać się poznaniem. Jedynie o nim [poznaniu] mogę powiedzieć, że coś przez nie myślę ( $K r V$ A 346/B 404).

${ }^{5}$ A. Brook, Kant and the Mind, Cambridge 1994.

${ }^{6}$ A. Dickerson, Kant on Representation and Objectivity, Cambridge 2007. 
Wstępnie można przyjąć, że zarysowuje się następujące rozumienie apercepcji. Transcendentalna apercepcja jest aktem źródłowym, „Ja myślę” (Ich denke), w którym można wyróżnić co najmniej dwa istotne aspekty: (1) stanowi for m ę wszelkiego przedstawienia, tj. formę świadomości; (2) jest s a moświ a domością (Selbstbewusstsein) uchwytującą istnienie własnego Ja. Te dwa aspekty transcendentalnej apercepcji wzajemnie się warunkują ${ }^{7}$. Transcendentalna apercepcja, rozpatrywana jako forma, jest przedstawieniem prostym, tzn. nie zawiera sama w sobie żadnej treści (różnorodności) ( $K r V$ A 355-6 i B 407), i dlatego nie daje ona żadnej wiedzy o tym, kim lub czym owo Ja [które myśli] jest. Kant podąża w tym samym kierunku, co Kartezjusz, który stwierdza: „(Ja) myślę, więc jestem (cogito, ergo sum)”:

$\mathrm{w}$ transcendentalnej syntezie różnorodności przedstawień $\mathrm{w}$ ogóle, a więc w syntetycznej pierwotnej jedności apercepcji, jestem świadom samego siebie nie takim, jakim się sobie przejawiam, ani nie tak, jakim jestem sam w sobie, lecz jedynie świadomy jestem tego, że jestem ( $K r V$ B 157).

W przeciwieństwie do Kartezjusza Kant nie wnioskuje jednak z tego twierdzenia o własnościach Ja, rozumianego jako podmiot metafizyczny, to znaczy podmiot transcendentalny, względnie noumenalne $\mathrm{Ja}^{8}$. Transcendentalna apercepcja jest co najwyżej związana z podmi o te m logi c znym, a nie substancjalnym. W krytyce substancjalnego charakteru transcendentalnej apercepcji Kant przypomina podejście Hume’a. Zarówno natura, jak też w konsekwencji status ontyczny transcendentalnej apercepcji pozostają więc niejasne. Można by ograniczyć się do charakterystyki negatywnej, w świetle której apercepcja nie jest substancją, nie jest Ja noumenalnym (jako podmiot), raczej jedynie wskazuje na ów podmiot. Możliwa wydaje się jednak charakterystyka pozytywna, zgodnie z którą transcendentalna apercepcja jest: (1) aktem źródłowym, pierwotnym; (2) formą wszelkiego przedstawienia, polegającą na nadawaniu jedności; (3) wskazuje na podmiot logiczny oraz (4) najwyższą zasadą. To, czy taka pozytywna charakterystyka transcen-

\footnotetext{
${ }^{7}$ Por. N. Kemp Smith, A Commentary to Kant's 'Critique of Pure Reason', London 2003, s. 262.

${ }^{8}$ Natomiast błąd, jaki zdaniem Kanta popełnia Kartezjusz (a za nim psychologia racjonalna) polega na tym, że hipostazuje on transcendentalną jedność apercepcji. Tzn. czyni z 'czystego pojęcia Ja' byt, któremu następnie przypisuje własności: prostoty, jedności, tożsamości numerycznej itd. (KrV A 382; A 395; A 400; A 384), jak o tym pisze Kant w rozdziale o paralogizmach.
} 
dentalnej apercepcji daje się spójnie pomyśleć, pozostaje zadaniem do szczegółowego zbadania.

\section{Apercepcja a sąd}

Wydaje się, że najbardziej owocny kierunek poszukiwań pozwalający zobrazować i rozwinąć pozytywną charakterystykę transcendentalnej apercepcji wiąże się z badaniem jej konstytutywnej roli w sądzie. Przytoczmy dwa określenia sądu, w których rola ta się uwidacznia:

sąd to nic innego, jak tylko sposób doprowadzania danych poznań do przedmiotowej jedności apercepcji ( $K r V$ B 141).

Sąd jest $[\ldots]$ pośrednim poznaniem przedmiotu, a więc przedstawieniem przedstawienia tego przedmiotu ( $\mathrm{KrV}$ A 68/B 93).

W sądzie dochodzi do utworzenia zło żo ny ch reprezentacji, czyli przedstawień. A to dokonuje się poprzez syntetyczną jedność, jaka jest wytwarzana przez transcendentalną apercepcję. Owa syntetyczna jedność jest nadawana pewnej różnorodności (Mannigfaltigkeit), tj. wielości przedstawień. Apercepcja jest aktem sądzenia, ściślej - fo r m ą aktu sądzenia: '( Ja ) myśl ę, ż e $p$ '. Sąd jest przedstawieniem II-go rzędu, rezultatem dołączania się transcendentalnej apercepcji (Ja myślę) do treści sądu. Schemat 'Ja myślę, że p' pokazuje wyraźnie, że owo 'Ja myślę' nie wchodzi w skład treści sądu; stanowi natomiast jego formę - jest ono czysto formalne, puste treściowo; forma ta ujmuje w określony, stały sposób treść.

Warto zwrócić uwagę, że analogiczne rozważania prowadzili analitycy: m.in. Frege, Russell, gdy usiłowali wyjaśnić jedność sądu, który jest czymś więcej niż tylko zwykłym zestawieniem pojęć. Musi być zatem jakaś zasada nadająca jedność pojęciom. Tę rolę - analogiczną do transcendentalnej apercepcji - zdaje się pełnić u Fregego i Russella a s e r cj a.

Wspomnianym analitykom zawdzięczamy wyraźne odróżnienie sądu rozumianego jako akt sądzenia (judgment/Urteil) od sądu w sensie logicznym (proposition), czyli pewnej abstrakcyjnej, ale już zsyntetyzowanej w sobie treści. Bliższe wejrzenie w rozpatrywane zagadnienie pozwala nam uświadomić sobie, że już wcześniej Kant nie tylko przeczuwał tego rodzaju rozwiązanie, 
ale sam przedstawił własne, głębsze i bardziej całościowe. Rozważmy kolejno poszczególne aspekty problematyki sądu u Kanta, co pozwoli jaśniej zobaczyć przenikającą ją transcendentalną jedność apercepcji, która występuje jako najwyższa zasada poznania.

W $\$ 19$ dedukcji B Kant wyraźnie stwierdza, że określenie sądu jako "przedstawienia pewnego stosunku między dwoma pojęciami” ( $K r V$ B 141) jest dalece niezadowalające. Od razu narzuca się, że przy takim rozumieniu sąd traktuje się jako sąd w s e n s i e lo g i c zn y m (proposition). Kant zgłasza dwie uwagi pod adresem takiego ujęcia. Po pierwsze, stosuje się ono poprawnie tylko do sądów kategorycznych, opartych na kategorii stosunku, ale już nie do pozostałych, tj. hipotetycznych i dysjunktywnych. Jest w tej uwadze Kanta zawarta ukryta krytyka wywodzącej się od Arystotelesa klasycznej teorii sądu, choć Frege i Russell przypisują sobie nowatorstwo, czyli odejście od tej teorii, polegające na uznaniu za pełnoprawne sądy o strukturze relacyjnej. Po drugie, powyższe określenie sądu nie wyjaśnia, „na czym ten stosunek polega", to znaczy nie mówi ono o tym, jaka jest ostateczna podstawa tego stosunku. Rozwijając własną koncepcję sądu, Kant twierdzi, że „sąd to nic innego, jak tylko sposób doprowadzenia danych poznań do przedmiotowej jedności apercepcji” ( $K r V$ B 141-2). A zatem to jedność transcendentalnej apercepcji jest poszukiwaną ostateczną podstawą stosunku występującego w samym sądzie, a przez „sposób doprowadzenia poznań do apercepcji” należy rozumieć kategorię. Po trzecie wreszcie, Kant nie mówi już dłużej o pojęciach (i sądzie jako stosunku między nimi), lecz o „danych poznaniach” (gegebene Erkenntnisse). W ten sposób rozszerza rozumienie/ujęcie sądu. Określenie „poznanie” sugeruje bowiem wzięcie pod uwagę nie tylko pojęć, ale również tzw. przedstawień naocznych (Anschauungen) ${ }^{9}$. Jeśli uznamy, że w sądzie mamy do czynienia $\mathrm{z}$ syntezą przedstawień dwojakiego rodzaju: pojęciami i przedstawieniami naocznymi, wtedy diametralnie zmienia się perspektywa, w jakiej odtąd musi być rozpatrywany sąd. Nie chodzi tu zatem o samo myślenie, ale o myślenie konfrontowane $\mathrm{z}$ tym, co dane w naoczności ${ }^{10}$; wtedy dopiero sąd jest sądem rozumianym jako akt sądzenia/osądzania

\footnotetext{
${ }^{9}$ Same pojęcia bez treści naocznej są „puste”, a przedstawienia naoczne bez pojęć „ślepe”dopiero połączenie jednych i drugich daje to, co Kant określa jako „poznanie” (Erkenntnis) (por. $K r V$ A 51/B 75).

${ }^{10}$ Przy czym chodzi tu o możliwość konfrontacji z tym, co dane w naoczności, tj. w pewnej przestrzennej i czasowej strukturze bądź ramie strukturalnej. Tę możliwość należy w pierwszym rzędzie rozumieć apriorycznie i transcendentalnie.
} 
[czegoś] o tym, co dane ${ }^{11}$. A zatem jest to przejście z poziomu sądu w sensie logicznym na poziom sądu, rozumianego jako akt sądzenia.

Sytuacja problemowa, jaką ma na uwadze Kant jest wysoce złożona, a przez empirystów i analityków na ogół niezbyt wyraźnie uświadamiana. Oto bowiem występują dwie płaszczyzny, z pozoru wzajemnie całkiem niezależne, z których pierwsza to płaszczyzna [czystego] intelektu, w której dokonywany jest kierowany kategoriami akt syntezy, w wyniku czego wytwarzany jest sąd w sensie logicznym. Druga - to płaszczyzna zmysłowej naoczności, gdzie za sprawą wyobraźni dokonuje się równoległa synteza, tzw. synteza postaciowa (figurliche Synthesis). Nie jest to całkiem ścisłe określenie procesu przebiegającego w płaszczyźnie zmysłowej naoczności, tam bowiem również, tj. w syntezie postaciowej, swój udział zaznaczają kategorie. Jest o tym mowa w znanym fragmencie pochodzącym z metafizycznej dedukcji kategorii:

Ta sama funkcja, która nadaje jedność różnym przedstawieniom w sądzie, daje również jedność samej tylko syntezie różnych przedstawień w naoczności. Jedność ta - ogólnie powiedziawszy - nazywa się czystym pojęciem intelektu. Ten sam więc intelekt, i to właśnie przez te same czynności, przez które za pośrednictwem jedności analitycznej wytworzył w pojęciach logiczną formę sądu, wprowadza też za pośrednictwem syntetycznej jedności tego, co różnorodne w naoczności w ogóle, w przedstawienia swoje pewną treść transcendentalną, dzięki której nazywają się one czystymi pojęciami intelektu, odnoszącymi się a priori do przedmiotów - coś, czego sprawić nie może logika ogólna. ( $\mathrm{KrV}$ A79/B105)

Rezultaty tych dwóch syntez: czysto intelektualnej w sądzie logicznym oraz syntezy postaciowej w zmysłowej naoczności zostają skoordynowane. W obu tych syntezach - obu dokonywanych przy współudziale kategorii ${ }^{12}$ - dochodzi do wytworzenia jedności kategorialnych. Kant dodaje, że konieczna jest jeszcze jedność ponadkategorialna, do której należy sprowadzić i w niej ze sobą skoordynować wytwory jedności kategorialnej. Tą poszukiwaną ponadkategorialną jednością jest właśnie transcendentalna jedność apercepcji. Wspomniane syntezy: w sądzie i w naoczności są tu traktowane niejako $\mathrm{w}$ izolacji; faktycznie jednak mamy do czynienia $\mathrm{z}$ konkretnym

${ }^{11}$ Tak jest w sądach syntetycznych; natomiast sądy analityczne nie wymagają konfrontacji z naocznością, a w konsekwencji z doświadczeniem.

${ }^{12}$ Ściśle rzecz biorąc, kategoriami nazywa Kant formy logiczne (bądź funkcje logiczne) w zastosowaniu do naoczności, tj. do tego, co różnorodne w naoczności. 
a kt e m sąd zenia (Urteil, judgment), który ma dwie strony, warstwy: pojęciową i naocznościową. Wydaje się, że faktyczne przedstawienie naoczne, to znaczy akt percepcji uważa Kant za akt sądzenia. W tzw. drabinie przedstawień określa on percepcję jako „przedstawienie ze świadomością,, a „percepcję przedmiotową" jako poznanie ( $K r V$ A 320/B 377). Mówiąc o percepcji jako o poznaniu, Kant wiąże z tym warunek „świadomości przedmiotowej”, czyli jest to dokładnie to samo, co rozumie on przez apercepcję transcendentalną, ściślej: przedmiotową jedność apercepcji [co zostanie nieco dalej dokładniej przeanalizowane]. Akt percepcji okazuje się w istocie aktem sądzenia, jest więc czymś więcej niż samo przedstawienie naoczne (Anschauung) ${ }^{13}$. W akcie percepcji rozumianym jako akt sądzenia dochodzi do głosu tzw. „dekomponująca synteza” (dekomponierende Synthesis) (KrV A 505/B 533). $\mathrm{W}$ akcie percepcji przedstawienia naoczne są dane jako już zsyntetyzowane dzięki wyobraźni. Natomiast sąd, czyli sąd percepcji jako faktyczne spostrzeżenie, jest wyodrębnieniem w całości pewnych określonych elementów, postaci i jednocześnie ich połączeniem - ukazaniem relacji między nimi. W rezultacie owej „dekomponującej syntezy” pojawia się sąd percepcji, a układ rozmaitych aspektów wyodrębnionych w całej sytuacji (czyli powiązanych ze sobą postaci/rzeczy) jest w istocie tym samym, co powiązanie pojęć ${ }^{14}$, synteza postaciowa bowiem, jakiej dokonuje wyobraźnia, jest kierowana kategorią. Jest to więc ujęcie wytworu syntezy wyobraźni w świetle kategorii. Można ową konkluzję sformułować nieco inaczej: gdy faktycznie wypowiadamy bądź zapisujemy sąd percepcji, wtedy jedynie jawnie wyrażamy akt sądzenia równoważny aktowi percepcji, stwierdzający istnienie pewnego stanu rzeczy; nie jest to więc nic innego, jak ujawnienie tego, co w sposób niejawny w samym akcie percepcji już jest zawarte.

Aby zapobiec nieporozumieniom związanym z tym, że powyższe analizy - na pierwszy rzut oka - ograniczają się do sądów percepcji, czyli do obszaru tego, co empiryczne, zwróćmy uwagę na to, że daje się wyróżnić dwa przypadki. Pierwszy, w którym sąd poprzedza przedstawienie naoczne, czyli percepcję (wąsko rozumianą), drugi - gdy sąd zostaje wydany na podsta-

\footnotetext{
${ }^{13}$ Pojawia się tu niejasność związana z Kantowskim rozróżnieniem sądów spostrzeżeniowych, tj. sądów percepcji i sądów doświadczenia (por. Prolegomena \$\$18-20); określenie „percepcja przedmiotowa" wyraźnie sugeruje, że chodzi w tym przypadku o sąd doświadczenia, a nie o sprawozdanie z czysto subiektywnego doznania. Wobec tego traktuję odtąd sąd percepcji jako sąd doświadczenia.

${ }^{14}$ Może ostrożniej należałoby powiedzieć, że chodzi tu o izomorficzność (a nawet tylko o homomorficzność).
} 
wie percepcji/przedstawienia naocznego. W pierwszym przypadku mamy do czynienia $\mathrm{z}$ aktem domniemania - tak to widzi Husserl i fenomenologowie, $\mathrm{w}$ drugim $-\mathrm{z}$ osądzeniem [treści] percepcji, to jest stwierdzeniem istnienia stanu rzeczy. Perspektywa, jaką się przy tym zakłada, jest perspektywą empiryczną. Jednakże Kantowi nie wyłącznie o empiryczne ujęcie chodzi, lecz przede wszystkim o transcendentalne rozważenie stosunku, $\mathrm{w}$ jakim sąd pozostaje do przedstawienia naocznego (percepcji); wtedy faktyczne następstwo czasowe/stosunek czasowy sądu i przedstawienia naocznego przestaje być ważne. Istotne natomiast pozostaje to, że to, co - z jednej strony - nazywamy sądem (sądem logicznym) i to, co - z drugiej - spostrzeżeniem bądź przedstawieniem naocznym, musi być uprzednio, to jest $\mathrm{z}$ góry skoordynowane. Kategorie „organizują nasze przedstawienia naoczne tak, by mogły się one nadawać do osądzania”, „wprowadzają w nie strukturę" potrzebną do tego, by sądy stosowały się do tych naoczności, to znaczy „przetwarzają naoczności w przedstawienia przedmiotów sądu" ${ }^{15}$. Na tym polega poszukiwana transcendentalna jedność, że „ta sama funkcja” (dieselbe Funktion), czyli kategoria rozumiana jako swoiste działanie/operacja, „nadaje jedność” zarówno w sądzie (logicznym), jak i w naoczności, to znaczy: sprowadza te dwa komplementarne ujęcia do transcendentalnej jedności apercepcji, ściślej: do przedmiotowej jedności apercepcji, która jest ostateczną, najwyższą i ponadkategorialną jednością. Sąd i pojęcia odnoszą się do przedstawień naocznych, a te ostatnie bezpośrednio do przedmiotu $(\mathrm{KrV} \text { A 68/B 93 })^{16}$. W ten sposób zostaje wytworzona aprioryczna i transcendentalna rama - st rukt u ra , w zgodzie z którą muszą pozostawać wszelkie nasze (empiryczne) akty poznawcze. Rola transcendentalnej apercepcji jest kluczowa w tym sensie, że stanowi ona $z$ as adę, według której owa a prioryczno-transcen-

${ }^{15}$ Por. P. Guyer, The Transcendental Deduction of Categories, [w:] Kant - Cambridge Companion, 1992, s. 130.

${ }^{16} \mathrm{H}$. Allison mówi w tym przypadku o „podwójnej determinacji przedmiotu sądu”; po pierwsze, przez podmiot logiczny, który bezpośrednio odnosi się do naoczności; po drugie, przez predykat, gdzie to drugie określenie dotyczy tego, co wcześniej zostało określone przez podmiot logiczny. Sąd wyraża więc relację pomiędzy tymi dwoma określeniami przedmiotu. Por. H. Allison, Kant's Transcendental Idealism, s. 71. Podobne uwagi zgłasza M. Heidegger, choć nieco inaczej rozkłada akcenty: „Jeśli orzeczenie ma być elementem poznania, to chodzi tu nie tyle o jego stosunek do podmiotu (orzeczeniowa synteza wypowiedzi), ile o jego (a lepiej: całej relacji podmiot-orzeczenie) „stosunek” do czegoś całkiem innego. To coś innego jest bytem samym, z którym poznawanie - a także odnośny stosunek sądzenia (Urteilsverhältnis) muszą pozostawać w zgodzie”. (Heidegger, Kant a problem metafizyki, przeł. B. Baran, PWN, Warszawa 1989, s. 130-131). 
dentalna struktura zostaje wytworzona. Wypada zatem dokładniej przyjrzeć się tej strukturze i poprzez bliższe jej zbadanie, objaśnić miejsce i rolę transcendentalnej apercepcji, jaką pełni ona $\mathrm{w}$ konstytuowaniu poszczególnych elementów owej struktury.

\section{Obiektywność i intencjonalność}

W celu dokładniejszego opisu tej struktury należy także wziąć pod uwagę kwestię przedmiotu, czyli problem obiektywnósi, który z jeszcze innej strony ukazuje zasadniczą rolę transcendentalnej apercepcji. W perspektywie kantowskiej przedmiot jest ujmowany w kontekście sądu. Kant, jak wiadomo, rozróżniał przedmiot rozumiany szeroko oraz wąsko. W szerokim rozumieniu każde przedstawienie (Vorstellung) jest przedmiotem, natomiast w wąskim - przedmiotem jest tylko fenomen, czyli zjawisko określone kategorialnie. Przedmiot jako fenomen jest możliwy tylko na gruncie sądu, a ten z kolei nie jest możliwy bez udziału transcendentalnej apercepcji. Problem obiektywności kryje w sobie inne zagadnienie, mianowicie kwestię intencjonalności, albowiem przedmiot wytworzony dzięki transcendentalnej apercepcji jest $\mathrm{w}$ istocie przedmiotem intencjonalnym. Transcendentalna apercepcja jest odpowiedzialna za wytworzenie semantycznego rysu naszych przedstawień. Inaczej mówiąc: intencjonalność, wytwarzana dzięki transcendentalnej jedności apercepcji, jest równoznaczna z semantycznym odniesieniem pewnej różnorodności (Mannigfaltigkeit) naszych przedstawień do przedmiotu.

Chodzi tu więc o syntetyczną jedność, którą transcendentalna apercepcja nadaje ${ }^{17}$ przedstawieniom i odnosi je do przedmiotu transcendentalnego $=\mathrm{X}$. Natomiast zwykła, tj. empiryczna apercepcja, tylko rejestruje przedstawienia (ich treść), ale nie interpretuje tej treści semantycznie ${ }^{18}$. Inaczej formułując, istnieje - zdaniem Kanta - zasadnicza różnica pomiędzy zwykłą, empiryczną apercepcją a apercepcją transcendentalną. Apercepcja empiryczna, czyli zmysł wewnętrzny, zatrzymuje się niejako na płaszczyźnie samych przedstawień, traktuje każde przedstawienie oddzielnie - jest, jak powiada Kant -

\footnotetext{
${ }^{17}$ Ściślej: kategorie doprowadzają do syntezy przedstawień (ich różnorodności), która z kolei jest doprowadzana do jedności w transcendentalnej apercepcji.

${ }^{18}$ Por. A. Dickerson, Kant on Representation and Objectivity, Cambridge 2007.
} 
„rozproszona” (zerstreut), tzn. zatomizowana; każde [świadome] przedstawienie jest oddzielnym aktem świadomości, a sam ów zmysł nie wystarcza do tego, by utworzyć określone złożone całości, które mogłyby stanowić przedmiot poznania. Akty te są liczne, stanowią pewną mnogość/różnorodność, a każde poszczególne przedstawienie można [analitycznie] rozdzielić i określić jako pewną treść ujętą w akcie (Apprehension), przez co zostaje jej nadana jedność. Pomiędzy aktem ujmowania a ujmowaną treścią przedstawienia występuje - można rzec - związek wertykalny. Niemniej wszystkie wspomniane akty pozostają niejako na tym samym poziomie, mogą być rozpatrywane jako pozostające w tej samej płaszczyźnie. Natomiast transcendentalna apercepcja ma być zdaniem Kanta czymś szczególnym, jedynym w swoim rodzaju aktem wykraczającym poza wszelkie poszczególne akty świadomości (apercepcji empirycznej), w którym ujmowane są owe akty, jako wypływające z pierwotnego źródła. Tym źródłem jest sama transcendentalna apercepcja [bądź jej podmiot $]^{19}$. Można tu mówić o „horyzontalnym” ujęciu wszystkich poszczególnych aktów świadomości [podmiotów empirycznych] w kolektywną całość/jedność przez transcendentalną apercepcję - byłaby to perspektywa „horyzontalna” ${ }^{20}$. Nie wydaje się jednak, by sprowadzenie poszczególnych aktów świadomości do pierwotnego źródła, tj. transcendentalnej apercepcji, następowało zupełnie bezpośrednio; w każdym razie Kant mówi o dwóch syntezach, które należy wyróżnić: syntezie odtwarzania w wyobraźni (Synthesis der Reproduktion) ${ }^{21}$ oraz syntezie rozpoznawania w pojęciu (Synthesis der Rekognition). Dlaczego nie wolno pomijać przyczynku, jaki wnoszą te dwie syntezy? Otóż, jak zauważa D. Pereboom (2010) ${ }^{22}$, transcendentalna apercepcja nie może odnieść się wprost i równocześnie do tych wszystkich poszczególnych aktów świadomości oraz zawartych w nich treści ${ }^{23}$. Stąd wyłania się potrzeba uprzedniego zsyntetyzowania treści występujących w tych aktach.

${ }^{19}$ Kwestia: czy zachodzi różnica pomiędzy samą transcendentalną apercepcją a jej podmiotem i na czym ona polega, zostanie rozwinięta nieco dalej. Niewątpliwie kryje się tu pewna trudność.

${ }^{20}$ Perspektywie horyzontalnej zostaje przeciwstawiona perspektywa "po trawersie” (transversal); por. M. Frank, Kant i problem świadomości siebie, „Przegląd Filozoficzny”, 2004, nr 4 (52), s. $263-274$.

${ }^{21}$ Synteza wyobraźni dokonuje się "przed apercepcją” (por. KrV A 118).

22 D. Pereboom, Kant's Metaphysical and Transcendental Deductions, [w:] A Companion to Kant, G. Bird (ed.), Willey-Blackwell, Oxford 2010, s. 154-168.

${ }^{23}$ Por. także H. Allison (1993): „[...] all my representations, in order to be representations for me, must possess synthetic unity, that is they must be connected in such a way as to allow for the possibility of being grasped together in one consciousness by a single 'I think'". H. Allison, 
Dokonuje tego wyobraźnia w syntezie odtwarzania; treść wcześniej przeżytych aktów zostaje przywołana i połączona $\mathrm{z}$ treścią obecnie przeżywanego aktu. Znaczy to, że różnorodność treści zostaje zebrana razem. Niemniej jednak, zebrana w ten sposób, czyli zsyntetyzowana treść nie daje jeszcze poznania. W każdym razie, aby można było mówić o poznaniu, zsyntetyzowana treść powinna zostać doprowadzona do transcendentalnej apercepcji. Aby to mogło nastąpić, konieczna jest nadto kolejna synteza, mianowicie synteza rozpoznawania w pojęciu. Synteza ta, dokonywana dzięki kategoriom, doprowadza zsyntetyzowaną w wyobraźni treść do jedności przedmiotowej. Doprowadzenie do rozpoznania w pojęciu, to jest do przedmiotowej jedności apercepcji [bądź przedmiotu transcendentalnego $=\mathrm{X}$ ] jest równoznaczne z tym, że następuje dołączenie „treści transcendentalnej” i w rezultacie dokonuje się akt transcendentalnej apercepcji.

\section{Numeryczna identyczność podmiotu i apercepcja}

Najważniejszym punktem przedstawionej konstrukcji teoretycznej Kanta jest założenie o konieczności ujęcia w jednej stale identycznej świadomości złożonego przedstawienia. Zasadnicze twierdzenie głosi, że "numeryczna identyczność [Ja] jest nieodłączna od pierwotnej apercepcji” (KrV A 113 i A 124). Znaczy to, że numeryczna identyczność Ja jest warunkiem koniecznym transcendentalnej apercepcji. Bez identycznego podmiotu "Ja myślę", podmiotu apercepcji, nie można by zebrać w jedno (sąd) wielu przedstawień i odnieść ich do przedmiotu, to jest doprowadzić do przedmiotowej jedności; bez identyczności podmiotu przedstawienia te pozostawałyby rozproszone. Transcendentalna jedność apercepcji i tożsamość podmiotu „Ja myślę" jest więc warunkiem koniecznym sądu, a w konsekwencji przedmiotu. Jednakże $\mathrm{z}$ drugiej strony, świadomość przedmiotu, tj. przedmiotowa jedność apercepcji jest także warunkiem koniecznym samoświadomości. Znaczy to, że jeżeli jestem świadomy samego siebie, to jestem świadomy przedmiotu (zewnętrznego). Transcendentalna apercepcja nie jest równoznaczna ze świadomością samego siebie ${ }^{24}$. Taka redukcja [rozumienia] apercepcji do samoświadomości

Apperception and Analyticity in the B-Deduction, "Grazer Philosophische Studien”, vol. 44, 1993, s. 233-252.

${ }^{24}$ Taką opinię wyrażają m. in. R. Zocher (1954), A. Brook (1994) i A. Dickerson (2004). 
byłaby tylko częściowo słuszna, świadomość samego siebie jest bowiem możliwa tylko dzięki świadomości przedmiotu zewnętrznego ${ }^{25}$.

Transcendentalną apercepcję należy rozumieć jako wstępny warunek wiedzy o numerycznej identyczności Ja (Selbst/self), a kolejnym warunkiem tej wiedzy jest świadomość przedmiotu zewnętrznego. Można następnie wykazać, że synteza kierowana kategoriami jest warunkiem koniecznym uzyskania takiej wiedzy, albowiem kategorie "konstytuują” przedmiot ${ }^{26}$. Wolno więc uznać, że sama identyczność Ja jest warunkiem koniecznym apercepcji, to znaczy jest ona także warunkiem [koniecznym] przedmiotowej jedności apercepcji, a co za tym idzie - także syntezy kierowanej kategoriami. Ale sama ta synteza, z kolei, jest warunkiem koniecznym wi ed zy $o$ identyczności Ja. Wywód ten może sprawiać wrażenie kolistości, albowiem musimy odwołać się do świadomości przedmiotów zewnętrznych - a więc do tego, co empiryczne - by uzyskać wiedzę o tym, co aprioryczne i transcendentalne ${ }^{27}$. Jeśli jednak cały czas mamy na uwadze odróżnienie: tego, co stanowi ów aprioryczny warunek oraz wi e d z ę $o$ nim (tj. o owym warunku), wtedy trudność znika. Zatem transcendentalna apercepcja może być uznana za swoisty, zupełnie niesprowadzalny do niczego innego akt świadomości, ściślej - formę aktu świadomości jako jego warunek - w którym ujmuje się jednocześnie dwa bieguny apriorycznej ramy: (1) identyczny podmiot Ja oraz (2) przedmiot, tj. przedmiotową jedność apercepcji, względnie przedmiot transcendentalny $=\mathrm{X}$, jako korelat tego podmiotu ${ }^{28}$. Dzięki transcendental-

\footnotetext{
${ }^{25}$ Stwierdza to Kant wyraźnie w tzw. odparciu idealizmu, że „tylko za pośrednictwem doświadczenia zewnętrznego jest możliwa świadomość naszego własnego istnienia” ( KrV B 277). ${ }^{26}$ Wydaje się, że również $\mathrm{H}$. Cohen unika w swej interpretacji wyraźnych deklaracji o redukcji transcendentalnej apercepcji do samoświadomości. „Transcendentalna apercepcja nie powinna tłumaczyć jedynie faktu psychologicznego, lecz ma wyjaśniać ten fundamentalny faktyczny stan świadomości, że obiektywizujemy treść zmysłu wewnętrznego, kształtujemy go jako przedmiot przedstawienia i poznania. Ostatecznie obiektywizacja polega na transcendentalnej apercepcji jako „subiektywnym warunku, który sam z siebie umożliwia, że tamte zjawiska zmysłu wewnętrznego zostają powiązane w 'tożsamości funkcji' w jednym i tym samym pojęciu”. I na tej samej stronie dodaje: „samą apercepcję uświadamiamy sobie w rozpoznawaniu w pojęciu." (H. Cohen, Kantowska teoria doświadczenia, przeł. A. Noras, Kęty 2012, s. 295). Cohen mówi także - w innym miejscu - wprost o „dwuznaczności apercepcji jako jedności kategorii i jako samowiedzy" (H. Cohen, s. 302).

${ }^{27} \mathrm{O}$ tym Kant pisze obszernie w przypisie do: $K r V$ B 422 (wyd. polskie t. 2, s. 133-134).

${ }^{28}$ Ważność owej apriorycznej ramy, tj. korelacji podmiot - przedmiot [i jej podstawy], podkreślają neokantyści, m.in. H. Rickert, Der Gegenstand der Erkenntnis, Tübingen 1928, s. 45-60; B. Bauch, Podmiot transcendentalny, przeł. A. Musioł, [w:] Neokantyzm badeński i marburski - Antologia tekstów, A. Noras i T. Kubalica (red.), Katowice 2011, s. 163-181;
} 
nej apercepcji możliwa jest samowiedza ${ }^{29}$, to znaczy uświadomienie, że bez identycznego podmiotu Ja nie byłoby możliwe sprowadzenie do jedności różnorodności przedstawień naocznych, tj. nadanie jej (różnorodności) postaci przedmiotowej jedności apercepcji. I odwrotnie, bez aktu sprowadzenia owej różnorodności do przedmiotowej jedności apercepcji ${ }^{30}$, nie byłbym świadomy tożsamości podmiotu [Ja]. Zatem jedno warunkuje drugie, tzn. numeryczna identyczność Ja i pierwotna apercepcja stanowią wzajemnie warunek konieczny i wystarczający ${ }^{31}$.

To, co najbardziej charakterystyczne dla transcendentalnej apercepcji i co ją odróżnia od samej tylko świadomości siebie, tj. samoświadomości, to fakt, że jest ona ujęciem jako jedność rozmaitych przedstawień, to znaczy ujęciem w jedności syntezy rozmaitych przedstawień. A co za tym idzie, jest także ujęciem jako jedno (i synteza) rozmaitych aktów świadomości. Dokonuje się to

oraz E. Cassirer, od którego pochodzi niezwykle celne sformułowanie, warte przytoczenia: "Jetzt erst ist das Verhältnis zwischen der inneren und der aüsseren Erfahrung, zwischen dem 'Selbstbewusstsein' und dem 'Gegenstandsbewusstsein' geklärt. Beide bilden keine für sich bestehende, gegeneinander selbständigen 'Hälften' der Gesamterfahrung; sondern sie sind an denselben Inbegriff allgemeingültiger und notwendiger logischer Voraussetzungen geknüpft und durch diesen Inbegriff hindurch aufeinander unlöslich bezogen. Wir fragen jetzt nicht mehr, wie das Ich zu den absoluten Dingen komme, noch wie die absoluten Dinge es anfangen, sich dem ich mitzuteilen: denn beides, das 'Selbst' wie der 'Gegenstand' ist für uns nunmehr der Ausdruck ein und derselben, im Begriff der transzendentalen Apperzeption beziechneten Grundgesetzlichkeit der 'Erfahrung überhaupt', durch deren Vermittlung es für uns allein Inhalte irgenwelcher Art., sei es des inneren, sei es aüsseren Sinnes, gibt" (E. Cassirer, Kants Leben und Lehre, Darmstadt 1975, s. 212).

${ }^{29}$ Ściśle rzecz ujmując: samoświadomość (Selbstbewusstsein); samoświadomość nie jest jeszcze samowiedzą. Termin „samowiedza” występuje w tłumaczeniu Ingardena, natomiast w tekście niemieckim konsekwentnie pojawia się Selbstbewusstsein. Tak też tłumaczy N. Kemp Smith jako self-consciousness, a u nas M. Żelazny.

${ }^{30}$ To sprowadzenie do jedności następuje w akcie sądzenia i [równolegle] w kierowanej kategoriami syntezie przedstawień w naoczności. Pozostaje to w zgodzie z postulatem Kanta głoszącym, że „ta sama funkcja, która nadaje jedność przedstawieniom w sądzie, daje również jedność w syntezie przedstawień w naoczności” ( $K r V$ A 79/B 105).

${ }^{31}$ Można ową równoważność ująć jako: nierozerwalne powiązanie (inescapable connection) pomiędzy samowiedzą (self knowledge) oraz wiedzą o przedmiotach. Por. P. Guyer, The Transcendental Deduction of the Categories, [w:] Kant. The Cambridge Companion, 1992, s. 155. Podobnie wypowiada się H. Allison: zachodzi relacja wzajemności (reciprocity) pomiędzy syntetyczną jednością apercepcji a przedstawieniem przedmiotu, a także - pomiędzy jednością świadomości a świadomością tej jedności. Por. H. Allison, Apperception and Analyticity in The B-Deduction, "Grazer Philosophische Studien”, vol. 44, 1993, s. 250. 
w sądzie ${ }^{32}$. Przedstawienie bowiem można rozumieć co najmniej dwojako: jako treść aktu przedstawiania bądź jako sam akt przedstawiania. Wydaje się, że transcendentalna apercepcja ujmuje jako jedno zarówno (1) rozmaitość treści aktów przedstawiania jak też (2) rozmaitość samych aktów przedstawiania. Temu ujmowaniu owej rozmaitości jako jedności [=syntetyczna pierwotna jedność apercepcji] towarzyszy nieodłączna świadomość jedności (!) [i jedyności!] samej tej pierwotnej świadomości, tj. transcendentalnej apercepcji. Albowiem tylko dzięki temu, że transcendentalna apercepcja jest jedna, może ująć razem wielość aktów świadomości, mających w niej samej swe źródło ${ }^{33}$.

Naszkicowany wyżej tok argumentacji wydaje się zgodny z tym, co Kant stwierdza w kluczowych fragmentach dedukcji A. Wychodzi on bowiem od określenia transcendentalnej apercepcji jako „czystej, pierwotnej, niezmiennej świadomości" ( $K r V$ A 107). Owa niezmienna świadomość implikuje jej identyczność (tożsamość). W kolejnym ujęciu Kant podkreśla jedność owej świadomości, czyli j e d n ość transcendentalnej apercepcji:

Ta zaś właśnie transcendentalna jedność apercepcji wytwarza ze wszystkich swoich możliwych zjawisk, które kiedykolwiek mogą razem występować w doświadczeniu, związek wszystkich tych przedstawień określony prawami. Ta bowiem jedność świadomości byłaby niemożliwa, gdyby umysł nie mógł w poznaniu tego, co różnorodne, stać się świadomym tożsamości funkcji, przez którą ona [jedność apercepcji] wiąże syntetycznie ze sobą to, co różnorodne, w jednym poznaniu. Pierwotna i konieczna świadomość tożsamości samego siebie jest więc zarazem świadomością równie koniecznej jedności syntezy wszystkich zjawisk, dokonywanej wedle pojęć, tzn. według prawideł [...] (KrV A 108).

Występują tu więc dwa aspekty owej jedności świadomości, jedności apercepcji. Po pierwsze, jest to jedność samej, ciągle tożsamej świadomości pierwotnej [=apercepcji]; po drugie - jedność przedstawień, tj. kolektywna jedność zsyntetyzowanych zjawisk. I wreszcie jako konkluzję można uznać uwagę Kanta, że: „czysta apercepcja” to tyle, ile „stała tożsamość samego sie-

32 „Aber die Urteilsstruktur ist doch für unsere Erkenntins von so unbestreitbar grundlegender Bedeutung, um dem Anspruch, in ihr und nur in ihr habe man die Identitätbedingungen für das Selbstbewusstsein zu sehen, hinreichende Plausibilität zu sichern" (D. Henrich, Identität und Objektivität, 1976, s. 109).

${ }^{33}$ Obszerne rozważania na ten temat można znaleźć w pracy M. Kilijanka, Kant. Samoświadomość i poznanie dyskursywne, Poznań 2000. 
bie przy wszystkich możliwych przedstawieniach” ( $\mathrm{KrV}$ A 116). Przez „stałą tożsamość samego siebie" należy rozumieć stałą tożsamość owej pierwotnej świadomości. Inaczej formułując, określenie „s stała tożsamość samego siebie” wskazujące niejako na pewne Ja, wskazuje w istocie na ową pierwotną, niezmienną świadomość. „Ja” jest innym - nieco mylącym - określeniem pierwotnej świadomości, czyli transcendentalnej apercepcji. Zbierając razem, jedność oraz identyczność to dwie niezbywalne własności transcendentalnej apercepcji ${ }^{34}$, stanowiące o tym, że jest ona podstawową $\mathrm{zd}$ oln o ści ią poznawczą, na której „źródłowo” opiera się „przedstawienie Ja” oraz przez którą „myślimy zjednoczoną różnorodność”35. W ten sposób uwidacznia się nierozerwalność dwóch aspektów transcendentalnej apercepcji, którą można rozumieć jako jedność świadomości oraz świadomość jedności, czyli jako jej dwa komplementarne ujęcia.

Transcendentalna apercepcja rozumiana jako syntetyczna jedność identycznego Ja bądź też jedność nadawana przez Ja, będąca formą wszelkiego aktu świadomości, jest najwyższą zasadą poznania. Znaczy to, że występuje ona $\mathrm{w}$ roli podobnej do praw fizyki, które same w sobie nie są przecież żadnymi bytami fizykalnymi, ani też siłami/oddziaływaniami, lecz określają z góry, w sposób konieczny, jak dane byty fizykalne/zjawiska będą się zachowywać pod wpływem określonych sił/oddziaływań, jakie będą mieć własności, tj. jak zjawiska będą przebiegać. Transcendentalna apercepcja nie jest więc żadnym konkretnym aktem świadomości ani nawet aktem samoświadomości, lecz war un ki e m możliwości owych aktów - występuje ona w tle wszystkich aktów. Jeśli więc twierdzi się, że transcendentalna apercepcja jest świadomością bądź aktem, to tylko w owym szczególnym sensie - jako źródłowy warunek wszelkich aktów świadomości. Aby oddać ów szczególny charakter transcendentalnej apercepcji, Kant posługuje się także terminem „świadomość w ogóle” (Bewusstsein überhaupt), który można rozumieć jako warunek wszelkiej świadomości ${ }^{36}$. Pozostaje jeszcze do ustale-

\footnotetext{
${ }^{34}$ Podkreśla to mocno D. Henrich w: Identität und Objektivität, Heidelberg 1976.

${ }_{35}$ Por. F. Grayeff, Deutung und Darstellung der teorethischen Philosophie Kants, Hamburg 1977, s. 179 i 186.

${ }^{36}$ Ciekawe rozważania dotyczące „świadomości w ogóle” i błędnych sposobów odczytania sensu tego określenia przeprowadza K. Jaspers w: Kant: Leben - Werke - Wirkung. München-Zürich 1983, s. 53-54.
} 
nia, jaka relacja zachodzi pomiędzy transcendentalną apercepcją a owym Ja, które myśli, czyli pomiędzy transcendentalną apercepcją a jej podmiotem ${ }^{37}$.

\section{Synteza i apercepcja}

Synteza, odgrywająca istotną rolę $\mathrm{w}$ doprowadzeniu przedstawień do przedmiotowej jedności apercepcji, jest aktem zasadniczo odmiennym od asocjacji. Pomiędzy koncepcją Hume’a, tłumaczącą naturę przedmiotów doświadczenia jako stale sobie towarzyszące kompleksy wrażeń, utworzone na drodze biernej asocjacji, a Kantowską koncepcją syntezy, w wyniku której konstytuowany jest fenomen, występuje znaczna różnica. Odwołajmy się do przykładu z dziedziny chemii, by ją wyraźniej ukazać. Asocjację można rozumieć jako zwykłe, mechaniczne zestawienie razem różnych elementów. Mamy np. dwa lub więcej składniki wyjściowe, które możemy ze sobą zestawić bądź zmieszać razem. W wyniku prostego zestawienia bądź zmieszania składników na ogół nie powstanie nic więcej ponad to, co włożyliśmy do reaktora; będziemy nadal mieli jedynie mieszaninę składników (nawet gdybyśmy tę czynność powtarzali wielokrotnie). Jeśli natomiast zamierzamy wytworzyć coś istotnie nowego, pewien związek chemiczny reagentów, musimy spełnić ściśle określone warunki: np. składniki zestawić w odpowiednich proporcjach, wynikających z zapisu reakcji chemicznych, zwiększyć ciśnienie w reaktorze, podgrzać reagenty, być może także wprowadzić szczególną atmosferę - czysty tlen bądź czysty azot, w której może zajść oczekiwana reakcja; być może konieczne ponadto jest, by zainicjować reakcję, zastosowanie specyficznego katalizatora. Po spełnieniu wymienionych warunków następuje synteza chemiczna, w wyniku której powstaje zupełnie nowa postać, nowy związek chemiczny, mający całkiem odmienne własności niż reagenty, czyli jego składniki. Owe ściśle określone i z góry narzucone warunki, w jakich można przeprowadzić syntezę chemiczną, stanowią odpowiednik warunków możliwości doświadczenia, tj. transcendentalno-apriorycznej ramy, o której mówi Kant. Synteza chemiczna jest analogiczna do tej, jaką ma na względzie Kant, będącej wynikiem aktywności, tj. samorzutności podmiotu, który jest czynnikiem transcendentalnym w stosunku do samych przedstawień.

${ }^{37}$ Pozostawiam ten punkt do szczegółowego opracowania w kolejnym artykule, który ma stanowić drugą część niniejszych rozważań. 
W konsekwencji dopiero dokonywane przez transcendentalną apercepcję zebranie $\mathrm{w}$ jedność zsyntetyzowanych rozmaitych przedstawień pozwala wytworzyć określoną całość, która nie jest ich zwykłą sumą, czyli agregatem, i odnieść ją intencjonalnie niejako p oza, tzn. zinterpretować ową całość jako przedmiot. Intencjonalne odniesienie - polegające na potraktowaniu agregatu przedstawień jako przedmiot, w pewnym sensie, „zewnętrzny” w stosunku do sumy owych przedstawień - można więc określić jako szczególne przekształcenie, transfor mację owego agregatu w nową postać, którą można uznać za właściwy przedmiot. Określenie „treść transcendentalna" (transzendentaler Inhalt) ${ }^{38}$, jakim posłużył się Kant w wyżej przywołanym kluczowym fragmencie ( $K r V$ A 79/B 104), można uznać za wskazujące na ową transformację, dzięki której dokonywane jest intencjonalne odniesienie. Treść ta powstaje dzięki transformacji przedstawień naocznych, dokonującej się za pośrednictwem kategorii, które doprowadzają ostatecznie różnorodność (wielość) przedstawień do przedmiotowej jedności apercepcji. Intencjonalne odniesienie realizuje się dzięki temu, że przedmiot transcendentalny $=\mathrm{X}$, czyli „przedmiotowa jedność apercepcji” ${ }^{39}$, jest szczególnym przedstawieniem; nie jest on/ono żadnym z przedstawień naocznych, lecz jako przedstawienie nienaoczne umożliwia wyjście niejako poza płaszczyznę przedstawień naocznych, a tym samym w pewien sposób ogranicza, domyka ów zbiór przedstawień naocznych - wspomniany agregat.

Wprowadzenie w przedstawienia [naoczne] treści transcendentalnej jest równoznaczne $\mathrm{z}$ przejściem z poziomu jedności subiektywnej na poziom jedności obiektywnej - na tym właśnie polega owa transformacja, sprawiająca, że różnorodność przedstawień będących subiektywnymi modyfikacjami [zmysłu wewnętrznego], staje się w jej wyniku przedmiotem [zewnętrznym], tj. przedmiotem poza sferą czysto subiektywną. Wytworzenie, przy współudziale kategorii, przedmiotowej jedności apercepcji, czyli szczególnego przedmiotu intencjonalnego, stanowi ostateczny punkt odniesienia - biegun ramy aprioryczno-transcendentalnej, który jest korelatem podmiotu transcendentalnego, $\mathrm{tj}$. podmiotu transcendentalnej apercepcji ${ }^{40}$. Pomiędzy tymi dwoma biegunami musi się znaleźć miejsce dla sądu logicznego i dla różno-

\footnotetext{
${ }^{38}$ Sens tego określenia nie jest całkiem jasny (por. H. Allison, Kant's Transcendental Idealism, 1983, s. 124).

${ }^{39}$ O tym, czy takie utożsamienie jest bez zarzutu, szerzej w dalszej części artykułu.

${ }^{40} \mathrm{Na}$ temat relacji: podmiot transcendentalny - przedmiotowa jedność apercepcji/przedmiot transcendentalny szerzej pisze J. Rolewski: Nowa metafizyka Kanta, Toruń 2002, szczególnie na s. $114-128$.
} 
rodności przedstawień w naoczności, to znaczy dla samej kombinacji pojęć w sądzie logicznym (gdzie występuje jedność analityczna) oraz syntetycznej jedności różnorodności przedstawień naocznych ${ }^{41}$ (ale rozpatrywanej wyłącznie subiektywnie - tj. w obrębie immanentnej sfery podmiotowej - jako tzw. jedność subiektywna). Dopiero odniesienie sądu logicznego, tj. pojęć w nim zawartych, do subiektywnej różnorodności w naoczności, kierowane kategoriami - wytwarzającymi przedmiotową jedność apercepcji - pozwala uzyskać pełnokrwisty akt sądzenia, w którym stwierdza się istnienie przedmiotu (fenomenu) o takich to a takich własnościach.

\section{Analiza sądu percepcji}

Przeprowadzone wyżej abstrakcyjne rozważania zilustrujmy przykładem, ukazującym rolę transcendentalnej apercepcji w tle zwykłych (empirycznych) sądów percepcji. Przeanalizujmy zatem sąd empiryczny „Ta róża jest czerwona”. Jest to najprostszy przykład sądu podmiotowo-orzecznikowego. Rozpatrując ów sąd w płaszczyźnie czysto pojęciowej, to jest intelektualnej, można w nim wyróżnić pojęcie róży, pojęcie czerwieni oraz łącznik ,jest”. Chociaż sąd ten jest niezwykle prosty, to nie jest on $o$ moim subiektywnym odczuciu tu i teraz wrażenia czerwieni, lecz o przedmiocie, który w pewien sposób wykracza, czyli transcenduje poza moje odczucie czerwieni, poza mój subiektywny stan mentalny. Kant podkreśla, że niepozorne słówko „jest”, odgrywające rolę łącznika (copula), gwarantuje obiektywny charakter tego sądu. Jest to więc sąd percepcji, dotyczący zewnętrznego, tj. transcen-

\footnotetext{
${ }^{41}$ Kwestia rozróżnienia przez Kanta jedności analitycznej oraz jedności syntetycznej jest niejasna. Wydaje się, że w przypadku sądu można tę różnicę rozumieć następująco. Pojęcia występujące w sądzie są przykładem jedności analitycznej; sam sąd jednakże jest przykładem syntezy pojęć, która jest ostatecznie zakotwiczona w przedmiotowej jedności apercepcji, tzn. sąd jest jednością syntetyczną. Mamy tu do czynienia z przykładem dekomponującej syntezy. Znaczy to, że punktem wyjścia jest pierwotna syntetyczna jedność apercepcji, następnie dokonujemy dekompozycji, tj. analizy, w wyniku której uzyskujemy pojęcia (np. pojęcie czerwieni), z kolei ponownie syntetyzujemy nową całość, czyli sąd, z tego, co otrzymane na drodze analizy, czyli z pojęć. I wreszcie dokonujemy kolejnej syntezy: sąd w sensie logicznym łączymy z tym, co różnorodne w naoczności i ostatecznie odnosimy do przedmiotu, tj. przedmiotowej jedności apercepcji.
} 
dentnego $^{42}$ (w słabym sensie!) przedmiotu względem mego Ja, podmiotu. $\mathrm{Na}$ czym polega rola kategorii $\mathrm{w}$ powyższym sądzie, traktowanym jedynie w perspektywie intelektualnej, czysto logicznej, czyli jako sąd logiczny? Pojęcie róży i pojęcie „bycie czerwonym” są pojęciami empirycznymi, natomiast kategoria określa sposób ich połączenia w sądzie logicznym. W analizowanym przykładzie jest to kategoria stosunku „przysługiwania czemuś i bycia podmiotem czegoś (substantia et accidens)" (KrV A 80/B 106). Kategoria ta jest jednym $z$ dwunastu sposobów, w jakie w sądach logicznych pojęcia empiryczne mogą się ze sobą łączyć. Kant powiada, że kategoria występuje tutaj jako „logiczna forma sądu” bądź „funkcja logiczna w sądzie” (KrV A 79/B $105)^{43}$. Takie ujęcie sądu i roli w nim kategorii dalekie jest jednak od zupełności, nie daje bowiem pełnego obrazu tego, czym jest sąd w pełnym znaczeniu, a nie tylko wzięty w abstrakcji jako sąd logiczny. Otóż w ogólności, sąd rozumiany jako akt sądzenia nie jest o stosunku między pojęciami, ale za pomocą owego stosunku ma się on odnosić do przedmiotu albo inaczej - do możliwego doświadczenia, to znaczy do przedmiotu występującego w możliwym doświadczeniu. Jest więc jasne, że w sądzie jako akcie sądzenia wykracza się poza sferę czysto intelektualną, czysto logiczną. Jeśli faktycznie widzę czerwoną różę i stwierdzam „Ta róża jest czerwona”, wtedy jest to sąd wydany w obliczu doświadczenia. Jednak Kantowi chodzi o to, że nie musi to być doświadczenie zrealizowane, ale wystarczy, że jest ono możliwe. Znaczy to, że można [i wystarczy] wyobrazić sobie czerwoną różę jako przedmiot możliwego doświadczenia, o którym jest ten sąd.

Obszar możliwego doświadczenia jako sfera, do której donosi się sąd, jest przeciwstawiony sferze czystego intelektu i logiki. Bazą dla doświadczenia (szczególnie zewnętrznego) jest receptywność naszych apriorycznych form zmysłowości: przestrzeni i czasu. Poprzez pobudzenia z zewnątrz tychże form doznajemy wrażeń (Eindrücke), z których wyobraźnia wytwarza przedstawienia naoczne (Anschauungen). Nie jest jednak tak, by wyłącznie wyobraźnia była zaangażowana w wytwarzanie przedstawień i syntetyzowanie ich mnogości, tj. różnorodności. Kant uważa, że wytwórcza wyobraźnia (produktive Einbildungskraft) współdziała w pewien sposób z kategoriami, ściślej - jest przez nie kierowana. W rezultacie współpracy kategorii z wyobraź-

\footnotetext{
${ }^{42}$ Oczywiście nie chodzi w tym wypadku o rzecz samą w sobie, ale o fenomen, przedmiot doświadczenia.

${ }^{43}$ Utożsamienie logicznej formy/funkcji w sądzie z kategorią jest usprawiedliwione wtedy, jeśli rozważamy sąd rozumiany jako akt sądzenia.
} 
nią możemy mówić o tzw. syntezie postaciowej (figurliche Synthesis), która wytwarza przedmioty doświadczenia, to jest zjawiska - ściślej: fenomeny jako stabilne kompleksy wielu elementarnych przedstawień naocznych. Jeśli wydajemy sąd „Ta róża jest czerwona”, to w sposób jawny określamy zmysłowo dane zjawisko, które już wstępnie zostało tak przygotowane - dzięki współdziałaniu wyobraźni z kategoriami ${ }^{44}$ - że teraz podlega dalszemu określaniu, determinowaniu za pomocą pojęć empirycznych ${ }^{45}$. Ale to dalsze determinowanie jest możliwe dzięki temu, że w tle tego kolejnego aktu determinowania obecna jest kategoria, która niejako wstępnie dostosowuje ${ }^{46}$ sferę zmysłowej naoczności do intelektualnego determinowania przez konkretne pojęcia empiryczne. To właśnie ma na uwadze Kant, gdy twierdzi, że „ta sama funkcja, która nadaje jedność różnym przedstawieniom w sądzie, daje również jedność samej tylko syntezie różnych przedstawień w naoczności” ( $K r V$, A 79/B104).

Opisywaną sytuację wydawania szczegółowego sądu percepcji można ująć $\mathrm{w}$ ten oto sposób. W danym nam zmysłowo bądź tylko wyobrażonym przedmiocie (możliwego) doświadczenia zjawisku/fenomenie wyodrębniamy dwa momenty: bycie różą i bycie czerwonym. W przedmiocie doświadczenia momenty te są zsyntetyzowane (jest to jedność syntetyczna), natomiast w sądzie logicznym są zestawione obok siebie (w jedności analitycznej). Zatem $\mathrm{w}$ akcie sądzenia za pomocą pojęć empirycznych determinujemy przedmiot dany w naoczności zmysłowej. Nie byłoby to możliwe, gdyby nie został spełniony podstawowy warunek, mianowicie jeśliby kategorie współdziałając w syntezie z wyobraźnią, nie wytwarzały równocześnie przedmiotowej jedności apercepcji (objektive Einheit der Apperzeption). Owa przedmiotowa jedność - stanowiąca biegun aprioryczno-transcendentalnej ramy, czyli k o relat transcendentalnego Ja, jest zarazem podstawą przedmiotu jako fenomenu. Kategorie, współdziałając z wyobraźnią, doprowadzają syntezę do

\footnotetext{
${ }^{44}$ Chodzi tu o wstępne kategorialne określenie zjawiska jako podlegającego kategorii „substancja i akcydens".

${ }^{45}$ Mowa jest o tym w następującym fragmencie: „to, co różnorodne, musi być dane oglądaniu jeszcze przed syntezą intelektu i niezależnie od niej” (KrV B 145).

${ }^{46}$ Można w tym przypadku mówić o „uzmysłowienu” (Versinnlichung) kategorii”. Por. G. Prauss, Kant und das Problem der Dinge an sich, Bonn 1989, s. 104, a także P. Strawson: „We could not employ any ordinary empirical concepts of objects unless our manifold perceptual experiences possessed the kind of coherence and interconnection which is required for the application of such concepts. Kant speaks of concepts of objects as rules governing the connection of experiences." P. Strawson, The Bound of Sense, Oxford 1966, s. 89.
} 
przedmiotowej jedności apercepcji, a sama apercepcja ujmuje syntezę, powstałą w wyniku tej współpracy, jako jedność.

Można teraz ponownie podjąć kwestię relacji pomiędzy apercepcją empiryczną a apercepcją transcendentalną. Na pierwszy rzut oka wydawać by się mogło, że akt percepcji jako akt świadomości empirycznej zawiera w sobie moment apercepcji empirycznej, ale pozbawiony jest apercepcji transcendentalnej. Niektóre wypowiedzi Kanta, w których stwierdza, że transcendentalna apercepcja jest świadomością siebie (por. $\mathrm{KrV}$ A $117^{*}$ przypis), mogą nasuwać tego rodzaju rozumienie. Ale jest to oczywiście błędne podejście. Gdyby istotnie tak było, wtedy w akcie percepcji byłbym świadomy jedynie swoich stanów wewnętrznych, ale nie mógłbym wiedzieć nic o przedmiotach zewnętrznych (fenomenach). Faktycznie jednak w percepcji, określanej przez Kanta jako „akt aprehensji”, jestem świadomy istnienia przedmiotów poza mną. Jest więc oczywiste, że w percepcji musi być obecny, bądź musi jej w pewien sposób towarzyszyć, moment apercepcji transcendentalnej, bez której nie mogłaby zostać osiągnięta jedność przedmiotowa, tj. przedmiotowa jedność apercepcji. Inaczej mówiąc, bez transcendentalnej apercepcji nie mogłaby wystąpić percepcja jako akt świadomości, mający wymiar semantyczny ${ }^{47}$.

${ }^{47}$ Należy zwrócić uwagę na dwie sprawy. Po pierwsze, Kant zajmuje niezbyt konsekwentne stanowisko w kwestii natury apercepcji empirycznej. Na ogół utożsamia ją ze zmysłem wewnętrznym, czyli tym czynnikiem, który czasowo porządkuje nasze stany mentalne, tj. przedstawienia. Niekiedy jednak Kant odróżnia apercepcję empiryczną i zmysł wewnętrzny, a wtedy apercepcja ta wydaje się czymś wyższym w stosunku do tego zmysłu. Źródłem zamieszania wydaje się przejęcie przez Kanta ustaleń terminologicznych Leibniza, które następnie zastosował do własnej teorii, czyli do filozofii transcendentalnej, co zaowocowało niejasnością i niekonsekwencją terminologiczną. Po drugie, niekiedy usiłuje się rozróżnić pomiędzy apercepcją empiryczną a apercepcją transcendentalną w ten sposób, że ta pierwsza byłaby świadomością treści, natomiast ta druga - świadomością własnego Ja (por. D. Weisman, Metaphysics, [w:] Rene Descartes - Discourse on Method and Meditations on First Philosophy - Text and Essays, 1996, s. 181). Takie rozwiązanie niesie w sobie tę groźbę, że percepcja - zredukowana do apercepcji empirycznej - traci wymiar semantyczny. Wydaje się, że można mimo to owo niebezpieczeństwo oddalić, mianowicie apercepcja empiryczna ma nadal wiązać się ze świadomością treści (być świadomością treści), natomiast apercepcja transcendentalna - wyrażająca się m.in. w zdaniu „Ja myślę" - jest świadomością for m y ! Z faktu, że percepcja jest aktem, w którym obecna jest apercepcja empiryczna, nie wynika, że brak w nim momentu apercepcji transcendentalnej. Rzecz w tym, że apercepcja transcendentalna nie polega na dodatkowym akcie refleksji, ale jest ona raczej p r e - r e fl e k s y j y m warunkiem samego aktu percepcji (a także aktu refleksji) oraz apercepcji empirycznej. Zważmy, że apercepcja transcendentalna jest ź r ó d ło w a , natomiast apercepcja empiryczna - wtórna. 


\section{Kant: prezentacjonista czy reprezentacjonista?}

W konkretnym sądzie percepcji „Ta róża jest czerwona” mamy do czynienia $\mathrm{z}$ wypełnieniem abstrakcyjnej aprioryczno-transcendentalnej ramy pojęciami empirycznymi z jednej strony, z drugiej - wrażeniami, które są obecne $\mathrm{w}$ empirycznych przedstawieniach naocznych. Wrażenia stanowią swoiste medium, poprzez które - $\mathrm{w}$ wyniku prostego ujęcia (Apprehension) w postać elementarnego przedstawienia naocznego - odnosimy się wprost, czyli bezpośrednio do przedmiotu. Proste przedstawienie naoczne/proste ujęcie wypełnione wrażeniami (traktowanymi jako jego treść) jest niejako przezroczyste $^{48}$. Tym, co bezpośrednio poznajemy nie są jednak wrażenia (ani nawet, jak się wydaje, proste przedstawienia naoczne ${ }^{49}$ ), ale przedmioty, czyli zjawiska, względnie fenomeny. Innymi słowy, przedmioty poznajemy poprzez wrażenia, będące treścią przedstawień naocznych. Dlatego Kant może powiedzieć, że przedstawienie naoczne odnosi się wprost do przedmiotu (por. $\mathrm{KrV}$ A 68/B 93). Jest więc usprawiedliwione nazwanie Kantowskiego podejścia do kwestii natury spostrzeżenia intencjonalną koncepcją percepcji. Rys intencjonalny tej teorii polega na tym, że treść wrażeniowa przedstawień naocznych, które - rozpatrywane same w sobie - są jedynie subiektywnymi stanami, modyfikacjami zmysłowości, zostaje dzięki syntetyczno-jednoczącemu działaniu wyobraźni i kategorii przetworzona, transformowana w przedmiotową jedność apercepcji. Jest to $\mathrm{w}$ istocie projektowanie przedmiotu/fenomenu, przy wykorzystaniu treści przedstawień naocznych jako surowego materiału. Nie można wobec tego przypisywać Kantowi poglądu, jakoby pierwszym, tj. bezpośrednim przedmiotem poznania były wrażenia, ani nawet ich elementarne ujęcia w przedstawienia naoczne. Kant stoi na stanowisku wręcz przeciwnym: pierwszymi i bezpośrednimi przedmiotami poznania są zjawiska/fenomeny - jest to teza empirycznego realizmu. Znaczy to, że nie wnioskujemy o istnieniu przedmiotów doświadczenia (=fenomenów) na podstawie wrażeń, ale odwrotnie ${ }^{50}$. W refleksji transcendentalnej usiłujemy na

\footnotetext{
${ }^{48}$ Same wrażenia także traktujemy jako w pewnym sensie „przezroczyste”.

${ }^{49}$ Proste przedstawienia naoczne można traktować jako wyglądy przedmiotów doświadczenia.

${ }^{50}$ We fragmencie zatytułowanym „odparcie idealizmu” (Widerlegung des Idealismus) Kant wprost stwierdza, że w przeciwieństwie do idealizmu przyjmującego, iż „jedynym bezpośrednim doświadczeniem jest doświadczenie wewnętrzne i że z niego się jedynie wnioskuje o rzeczach zewnętrznych, ale - jak zawsze wtedy, gdy z danych skutków wnioskuje się o okreś-
} 
drodze analizy redukcyjnej ustalić, jakie warunki muszą zostać spełnione i jakie warstwy w akcie spostrzeżenia należy wyróżnić, aby uzasadnić to, co jest dla nas bezpośrednio oczywiste, czyli bezpośrednie poznanie fenomenów. $\mathrm{Na}$ drodze takiej analizy dochodzimy do wrażeń jako do tego, co - w pewnym szczególnym sensie - jest bezpośrednio dane, ale wrażenia są tym, co musimy niejako założyć, a nie tym, co bezpośrednio poznajemy ${ }^{51}$. Okazuje się, że Kant zajmuje stanowisko zbliżone do tego, jakie można przypisać Th. Reidowi. Obaj odrzucają Hume’owski sceptycyzm biorący się stąd, że uznał on, iż bezpośrednimi przedmiotami poznania są impresje, czyli inaczej - dane zmysłowe (sense data) bądź wrażenia. O ile jednak Reidowi można zarzucić dogmatyzm, gdyż zatrzymuje się on na stwierdzeniu, że pewność bezpośredniego poznania rzeczy opiera się na nieodpartej sile pierwotnego przekonania (suggestion), to Kant stara się uzasadnić swój empiryczny realizm. Krytyczna argumentacja prowadzi go z kolei do transcendentalnego idealizmu, który da się sprowadzić do stwierdzenia, że chociaż przedmioty doświadczenia, czyli fenomeny poznajemy bezpośrednio, to jednak okazują się one ostatecznie naszymi konstrukcjami ${ }^{52}$, a nie rzeczami samymi w sobie, istniejącymi całkowicie niezależnie od naszych władz poznawczych.

lonych przyczynach - tylko w sposób niepewny, gdyż przyczyna przedstawień, którą przypisujemy - być może błędnie - rzeczom zewnętrznym, może leżeć także w nas samych. Tutaj natomiast udowadnia się, że z e w n ę t r z n e doświadczenie jest właściwie b e z p oś r e d n i e [podkr. - W. H.], że tylko za jego pośrednictwem jest możliwa [...] świadomość naszego własnego istnienia." (KrV B 276-77, t. 1, s. 402). Dalej idące analizy dotyczące bezpośredniości doświadczenia zewnętrznego można znaleźć w artykule D. Perebooma: Kant on Intentionality, „Synthese”, vol. 77, 1988, s. 321-352.

${ }^{51}$ Pomimo zdecydowanej deklaracji bezpośredniości poznania przedmiotu w tzw. odparciu idealizmu, występuje ciągła dwuznaczność dotycząca kwestii roli i pozycji wrażeń w modelu poznania, jaki proponuje Kant. O tym pisze szerzej m.in. P. Kozak, Co to jest myślenie? Pojęcia, sądy, percepcja w perspektywie kantowskiej, Scholar, Warszawa 2015, s. 58-59. Można zauważyć u Kanta podwójny, a może nawet potrójny, sens wyrażenia „to, co dane”: (1) same wrażenia; (2) przedmioty doświadczenia; (3) przedstawienia naoczne (Anschauungen). Kwestia statusu wrażeń pojawia się także jako ważny motyw w rozważaniach Ingardena, w: $Z$ badań nad filozofia współczesną, PWN, Warszawa 1963, s. 274 (przypis). Za prezentacjonizmem Kanta zdaje się też opowiadać D. Henrich: „Nun sind aber jene Daten an ihnen selbst gar keine möglichen Gegenstände für unsere Erkenntnis, die kraft dessen, dass sie in Urteilen Erfolg, immer schon auf komplexe Gegenstände orientiert ist." Por. D. Henrich, Identität und Objektivität, Heidelberg 1976, s. 42.

${ }^{52}$ Należy jednak pamiętać, że materiał do tych konstrukcji (wrażenia) pochodzi z zewnątrz, od rzeczy samych w sobie; ta uwaga jest istotna, ponieważ odróżnia zdecydowanie stanowisko Kanta od podejścia obecnego w idealizmie absolutnym Fichtego, Schellinga i Hegla. 
Dokonana wyżej próba analizy roli wrażeń i przedstawień naocznych bezpośrednio odnoszących się do przedmiotu, pozwala wyraźniej odczytać sens jednego z kluczowych określeń sądu, jakie sformułował Kant: „sąd jest pośrednim poznaniem przedmiotu, a więc przedstawieniem przedstawienia tego przedmiotu" ( $\mathrm{KrV}$ A 68/B 93). Sąd jako przedstawienie drugiego stopnia jest swoistym aktem syntezy i analizy jednocześnie, który odnosi się do produktu syntezy dokonanej w naoczności, tzn. do przedstawień w naoczności (formy naoczności + wyobraźnia). Ta pierwsza synteza w naoczności wstępnie wyodrębnia przedmiot, tj. formuje go kategorialnie jako przedmiot w ogóle. Z kolei, zachodząca w sądzie synteza drugiego stopnia, dokonuje dalszego determinowania przedmiotu dzięki temu, że do struktury kategorialnej (wcześniej obecnej w naoczności) dołącza określenia empiryczne ${ }^{53}$. Kategorie określają jedynie "przedmiot w ogóle” (Gegenstand überhaupt), to znaczy określają wyłącznie strukturę głęboką przedmiotu jako przedmiotu, natomiast dopiero pojęcia empiryczne $\mathrm{w}$ sądzie syntetycznym a posteriori determinują dalej strukturę powierzchniową (coś jak gdyby przypadłości). Inaczej mówiąc, przedmiot w ogóle (czyli przedmiotowa jedność apercepcji) musi być już a priori transcendentalnie założony, by można go [było] określać empirycznie ${ }^{54}$.

Humeo’wski atomizm w kwestii przedmiotów doświadczenia, jako wyłącznie asocjacjonistycznie wytworzonych kompleksów z wewnętrznych stanów mentalnych, czyli impresji/idei (posiadających wyłącznie przygodną jedność subiektywną), zostaje przezwyciężony przez Kantowski holiz m ${ }^{55}$, który każe widzieć fenomen jako transcendentalnie zsyntetyzowaną treść przedstawień naocznych, to znaczy jako wytwór projekcji mający walor powszechności i konieczności ${ }^{56}$. Dokonuje się to dzięki kategoriom, stanowiącym [transcendentalne] normy, sprowadzające wspomnianą treść do obiektywnej jedności, to jest do przedmiotowej jedności apercepcji.

\footnotetext{
${ }^{53}$ W rozpatrywanym wyżej przykładzie określeniami tymi są: „róża” i „bycie czerwonym”.

${ }^{54}$ Celną uwagę zgłasza w tej kwestii M. Frank: „kategorie odpowiedzialne za transcendentalną idealność obiektów może też Kant nazwać predykatami przedmiotów w ogóle (przy czym wyrażenie 'w ogóle', znaczy tylko tyle, że kategorie współkonstytuują jedynie obiektywność przedmiotów, a nie ich realne istnienie i nie odpowiadają za to, że tu mamy do czynienia z jaszczurką, tam z krzesłem, a jeszcze gdzie indziej z asteroidem.” M. Frank, Główna myśl Kanta, przeł. Z. Zwoliński, „Przegląd Filozoficzny” 2004, nr 4 (52), s. 69.

${ }^{55}$ Holizm Kanta wyraża się najpełniej w pojęciu „transcendentalnej pierwotnej syntetycznej jedności apercepcji”.

${ }^{56}$ Jest to tzw. obiektywna ważność bądź obowiązywalność (objektive Gültigkeit).
} 


\section{Uwagi końcowe}

W świetle powyższych rozważań istota transcendentalnej apercepcji zarysowuje się jako szczególny „Związek między świadomością siebie, obiektywnością i strukturą propozycjonalną" ${ }^{57}$. Transcendentalna apercepcja jest więc swoistym, źródłowym aktem, ściślej - formą wszelkiego aktu świadomości; okazuje się ona tym, w czym da się wyróżnić trzy momenty: szczególne, tj. bezpośrednie ${ }^{58}$ odniesienie do Ja, konstytuowanie przedmiotu i ujmowanie przedstawień w postać sądu. Jest to możliwe dzięki s t a ł o ś c i, n u m e r y c z nej identyczności oraz pustemu charakterowi transcendentalnego Ja, transcendentalnej apercepcji; są to warunki, które muszą zostać założone po to, by móc wyjaśnić dokonywanie syntezy różnych przedstawień, poprzez doprowadzenie ich do jedności; innymi słowy - by uzyskać przedmiotową jedność apercepcji, nadając tym samym intencjonalny rys naszym przedstawieniom.

Stwierdzenie, że transcendentalna apercepcja wyznacza pewien związek pomiędzy samoświadomością, strukturą propozycjonalną i konstytuowaniem przedmiotu, jest oczywiście dalekie od jej (tj. apercepcji) pełnej charakterystyki. Przede wszystkim, wiele wskazuje na to, że nie można utożsamiać transcendentalnej apercepcji z refleksyjnie rozumianym aktem samoświadomości „Ja myślę" bądź do niego zredukować ${ }^{59}$. Jest raczej odwrotnie, refleksyjna świadomość jako następstwo aktu „Ja myślę”, jest czymś wtórnym wobec transcendentalnej apercepcji. Wydaje się, że Kant nie jest zwolennikiem refleksyjnej teorii świadomości, raczej jest on prekursorem podejścia Fichtego, który głosił, że takie refleksyjne ujęcie prowadzi do regresu do nieskończoności. Zatem należy przyjąć, że transcendentalna apercepcja jest czymś pierwotnym, czymś, co umożliwia wszelkie akty - w tym akty refleksyjne. Transcendentalna apercepcja może być - w interpretacji psychologizującej pre-refleksyjnym odczuciem/świadomością Ja, bądź - w ujęciu logicyzującym - mo żli wo ści ą wszelkiej świadomości.

\footnotetext{
${ }^{57}$ M. Frank, Świadomość siebie i poznanie siebie, przeł. Z. Zwoliński, Oficyna Naukowa, Warszawa 2002, s. 359.

${ }^{58}$ Bezpośrednie, tzn. nie refleksyjne.

${ }^{59}$ To, czy wolno utożsamiać akt „Ja myślę” z transcendentalną apercepcją, jest punktem spornym. Nie mogę w tym artykule szerzej zająć się tą sprawą; będzie ona natomiast przedmiotem rozważań w kolejnym tekście, który przygotowuję.
} 
Punktów spornych dotyczących transcendentalnej apercepcji jest znacznie więcej. Wspomnieć tu należałoby m.in. o relacji transcendentalnej apercepcji do ostatecznego podmiotu, to jest do Ja noumenalnego; podobnie niejasna pozostaje relacja wyobraźni do transcendentalnej apercepcji, a także stosunek kategorii do transcendentalnej apercepcji wymaga dokładniejszego omówienia, wreszcie pozostaje kwestia, czy zasada transcendentalnej apercepcji jest twierdzeniem analitycznym czy syntetycznym. Wszystkie wymienione zagadnienia wymagają osobnego omówienia ${ }^{60}$.

\section{Bibliografia}

Allison Henry, Kant's Transcendental Idealism. An Defence and Interpretation, New Haven-London 1983.

Allison Henry, Apperception and Analyticity in the B-Deduction, "Grazer Philsophische Studien", vol. 44, 1993, s. 233-252.

Bauch Bruno, Podmiot transcendentalny. Zarys transcendentalno-filozoficzny, przeł. A. Musioł, [w:] Neokantyzm badeński i marburski. Antologia tekstów, A. Noras i T. Kubalica (red.), Wydawnictwo Uniwersytetu Śląskiego, Katowice 2011, s. $163-181$.

Cassirer Ernst, Kants Leben und Lehre, Wissenschaftliche Buchgesellschaft, Darmstadt 1975.

Cohen Hermann, Kantowska teoria doświadczenia, przeł. A. Noras, Wydawnictwo Marek Derewiecki, Kęty 2012.

Dickerson Adam, Kant on Representation and Objectivity, Cambridge 2007.

Brook Andrew, Kant and the Mind, Cambridge University Press, Cambridge 1994.

Frank Manfred, Świadomość siebie i poznanie siebie, przeł. Z. Zwoliński, Oficyna Naukowa, Warszawa 2002.

Frank Manfred, Główna myśl Kanta, przeł. Z. Zwoliński, „Przegląd Filozoficzny Nowa Seria”, R. 13, nr 4 (52), Warszawa 2004, s. 61-75.

Frank Manfred, Kant i problem świadomości siebie, przeł. Z. Zwoliński, „Przegląd filozoficzny - Nowa Seria", R. 13, nr 4 (52), Warszawa 2004, s. 263-274.

Grayeff Felix, Deutung und Darstellung der theoretischen Philosophie Kants, Felix Meiner Verlag, Hamburg 1977.

Guyer Paul, Kant and the Claims of Knowledge, Cambridge 1987.

${ }^{60}$ Analizę wskazanych problemów zamierzam przeprowadzić w kolejnym tekście, który wraz z niniejszym artykułem będzie stanowić całość. 
Guyer Paul, The Transcendental Deduction of Categories, [w:] Guyer P. (ed.) Kant Cambridge Companion, Cambridge, 1992, s. 129-154.

Heidegger Martin, Kant a problem metafizyki, przeł. B. Baran, PWN, Warszawa 1989. Henrich Dieter, Identität und Objektivität, Carl Winter Universitätsverlag, Heidelberg 1976.

Howell Robert, Kant, the 'I think' and Self-Awareness, [w:] P. Cicovacki (ed.) Kant's Legacy, University of Rochester Press, New York 2001, s. 117-152.

Jaspers Karl, Kant: Leben - Werke - Wirkung, Pieper Verlag, Münich - Zürich 1983. Judycki Stanisław, Kantowska teoria umysłu, „Roczniki Filozoficzne”, t. XLV, 1997, z. 1, s. 35-60.

Kant Immanuel, Kritik der reinen Vernunft, B. Erdmann (hrsg.), Walter de Gruyter, Leipzig 1923.

Kant Immanuel, Krytyka czystego rozumu, przeł. R. Ingarden, PWN, Warszawa 1957.

Kant Immanuel, Krytyka czystego rozumu, przeł. M. Żelazny, Wydawnictwo Naukowe UMK, Toruń 2013.

Kant Immanuel, Prolegomena do wszelkiej przyszłej metafizyki, przeł. B. Bornstein, PWN, Warszawa 1960.

Kemp Smith Norman, A Commentary to Kant's 'Critique of Pure Reason', MacmillanPalgrave, New York 2003.

Kilijanek Marek, Kant. Samoświadomość i poznanie dyskursywne, Wydawnictwo UMA, Poznań 2000.

Klass Gregory M., A Framework for Reading Kant on Apperception: Seven Interpretive Questions, "Kant Studien” Bd. 94, 2006, s. 80-94.

Kozak Piotr, Co to jest myślenie? Pojęcia, sądy, percepcja w perspektywie kantowskiej, Scholar, Warszawa 2015.

Pereboom Derk, Kant on Intentionality, “Synthese”, vol. 77, 1988, s. 321-352.

Pereboom Derk, Kant's Metaphysical and Transcendental Deductions, [w:] A Companion to Kant, G. Bird (ed.), Willey-Blackwell, Oxford 2010, s. 154-168.

Prauss Gerold, Kant und das Problem der Dinge an sich, Bouvier Verlag, Bonn 1989.

Rickert Heinrich, Der Gegenstand der Erkenntnis, J. Mohr (Paul Siebeck), Tübingen 1928.

Rolewski Jarosław, Nowa metafizyka Kanta, Wydawnictwo Rolewski, Toruń 2002.

Strawson Peter, The Bound of Sense, Oxford 1966. 


\section{Abstract \\ Apperception and Judgment. Reflections on the Transcendental Deduction of Categories}

In the present paper I discuss the different ways of describing transcendental apperception (TA) that we encounter in Kant's Critique of Pure Reason. The question is: do these definitions together yield a coherent characterization of TA? I analyze an interpretation that identifies TA with self-consciousness, with a reflexive act. Such an understanding does not seem entirely correct. A more appropriate would appear (to be) an interpretation that begins with the role that TA plays in imposing unity on different presentations in judgment. From this perspective TA reveals itself as the factor responsible for creating the intentional feature of empirical acts, and ultimately, as the necessary condition of an object as a phenomenon. Moreover, when we define TA as "the highest principle" we can treat it as something analogous to the laws or principles of physics.

Keywords: Kant, apperception, judgment, category, unity, synthesis, identity, intentionality, consciousness, self-consciousness, subject 